\title{
Ammar Al-Tabbaa, The Ex Ante and Ex Post Application of the Teckal Criteria for In-house Awards (Uprzednie oraz następcze zastosowanie kryteriów Teckal w ramach zamówień in-house), „European Public Procurement and Public Private Partnership Law Review" 2016, vol. 11, iss. 3, s. 166-178, DOI: https://doi.org/10.21552/epppl/2016/3/7.
}

Zaprezentowane w artykule refleksje dotyczą kwestii temporalnego stosowania wypracowanych przez TSUE, a następnie inkorporowanych do dyrektyw zamówieniowych kryteriów Teckal. Rozważania autora stanowią element toczącej się w przestrzeni zamówień publicznych dyskusji odnoszącej się do zakresu, w jakim dorobek orzeczniczy TSUE, którym wykreowano reguły dotyczące zamówień typu in-house, pozostaje aktualny po skodyfikowaniu tej materii w dyrektywach zamówieniowych oraz krajowych aktach normatywnych, z wykorzystaniem których nastąpiła implementacja regulacji unijnych.

Ammar Al-Tabbaa rozważaniami czynionymi w artykule zmierza do ustalenia, czy kryteria Teckal, dozwalające na odstąpienie od stosowania regulacji dyrektyw zamówieniowych, muszą zostać spełnione wyłącznie przed zawarciem umowy w sprawie zamówienia publicznego, czy muszą również aktualizować się w trakcie wykonywania zobowiązań kontraktowych, a ponadto czy niezbędne jest weryfikowanie zaktualizowania się ich na różnych etapach procesu udzielania i realizacji zamówienia. Konkretyzując, autor zmierza do ustalenia, czy reguła - wyrażona przez TSUE w wyroku z 10 września 2009 r. w sprawie C-573/07 (Sea Srl v. Comune di Ponte Nossa), doprecyzowująca m.in. aspekt temporalny jednego z kryteriów Teckal, dotyczącego zakazu udziału kapitału prywatnego w kontrolowanej osobie prawnej - powinna być rozszerzana na pozostałe kryteria. Wskazane orzeczenie TSUE dookreśla, że brak udziału kapitału prywatnego w osobie kontrolowanej jest warunkiem sine qua non nie tylko zgodnego z prawem udzielenia zamówienia in-house, lecz również jego realizacji. W konsekwencji zmiana sytuacji faktycznej wywołująca dezaktualizację spełniania kryteriów Teckal skutkuje koniecznością rozwiązania stosunku kontraktowego ustanowionego na podstawie reguł kreujących wyjątek umożliwiający udzielenie zamówienia bez zastosowania regulacji dyrektyw zamówieniowych oraz aktów transponujących je do wewnętrznych porządków prawnych poszczególnych państw członkowskich Unii Europejskiej.

Punktem wyjścia rozważań czynionych przez autora jest skonstatowanie ustanowienia jako reguły wiodącej obowiązku ustalenia wszystkich kwestii związanych z udzielaniem zamówienia przed wszczęciem stosownej procedury lub udzieleniem zamówienia. Zasada pewności prawa nakazuje, by zamawiający zbadał możliwość zastosowania poszczególnych przewidzianych w regulacjach normatywnych rozwiązań na etapie przygotowania postępowania. Jedynie w drodze wyjątku istnieć może reguła nakazującą podjęcie czynności weryfikacyjnych również na etapie realizacji zamówienia. Rozwiązanie takie, jako wyjątek od reguły wiodącej, musi charakteryzować się silnym uzasadnieniem, np. popartym okolicznością, że bezwzględne przestrzeganie reguły wiodącej skutkowałoby koniecznością usankcjonowania obejścia prawa przez zamawiających lub wykonawców.

W ocenie autora wyjątki takie powinny być przewidywane możliwie najrzadziej, albowiem zasadniczy zakres normowania dyrektyw zamówieniowych obejmuje 
etap kontraktowania, a w konsekwencji reguły zmierzające do ochrony konkurencji w prawie zamówień publicznych powinny pozostawać $\mathrm{z}$ nim $\mathrm{w}$ bezpośrednim związku. Zjawiska występujące na etapie realizacji zamówienia są objęte zakresem przedmiotowym innych aktów normatywnych, w tym współtworzących obszar prawa antymonopolowego oraz prawa pomocy publicznej. Autor uznaje, że nie ma wystarczająco mocno uzasadnionych względów, w tym wiążących się z możliwymi zakłóceniami konkurencji, które przemawiałyby za zasadnością rozszerzenia katalogu kryteriów Teckal, które powinny być weryfikowane również następczo, poza zakres wyznaczony orzeczeniem TSUE w sprawie C-573/07. Obowiązujące regulacje dotyczące naruszenie uczciwej konkurencji oraz niedozwolonej pomocy publicznej przewidują wystarczająco skuteczne mechanizmy pozwalające na zwalczanie ewentualnych naruszeń reguł rynkowych w trakcie realizacji zamówień in-house. Odniesienie wskazanej reguły do wszystkich kryteriów Teckal skutkowałoby znacznym usztywnieniem stosunków zachodzących w trakcie realizacji zamówienia w sposób nieproporcjonalny do ewentualnie mogących wystąpić naruszeń zasad uczciwej konkurencji. Ponadto rozszerzenie zakresu kryteriów, których weryfikacja obligatoryjnie przeprowadzana jest również na etapie realizacji zamówienia, mogłoby wywoływać daleko idące konsekwencje, m.in. w sytuacjach chwilowych oraz przejściowych zmian, w tym również w przypadkach, w których modyfikacje te znajdują powszechnie akceptowalne uzasadnienie. Automatyzowanie regulacji w nieuzasadniony sposób może negatywnie wpłynąć na stosunek łączący strony w sytuacjach, w których nie istnieje realne ryzyko naruszenia istotnych wartości, w tym związanych z konkurencją rynkowa, a więc tych, których zagrożenie w kontekście zamówień in-house jest najczęściej podnoszone. 